\title{
Konsep 5W+1H dalam Pendidikan (Komparasi Pemikirian Ki Hajar Dewantara dan K.H. A. Wahid Hasyim)
}

\author{
Iin Supriyanti, M.Pd.I \\ Dosen Tetap IAI Riyadlotul Mujahidin Ngabar
}

\begin{abstract}
Abstrak
Education is a conscious effort given by a person through a learning process to form a generation of character, knowledge and religion. Education itself is given by anyone who has more knowledge to humans who have not yet learned. With education it is expected to be able to increase the potential that exists in humans. Speaking of education, there are several figures who play a role in building, optimizing and shaping an education. By looking at the explanation above, the need for an understanding in society about education. In this article, we will discuss aspects of education in $5 \mathrm{~W}+1 \mathrm{H}$. Namely What is the meaning of education? Who is the real educator? Why is education needed? When is education going on? Where is the education carried out? Abdul Wahid Hasyim was born on June 1, $1914 \mathrm{AD}$ or to coincide with the 5th Wed 'al-awwal $1333 \mathrm{H}$ in Jombang, East Java. He is the son of K.H Hasyim Asy'ari, founder of Nahdlatul Ulama. Ki Hadjar Dewantara was born in Yogyakarta on May 2, 1889. He was the fifth son of Soeryaningrat, the son of Paku Alam III. When he was born, he was given the name Soewardi Soeryaningrat, because he was still of royal descent, he was awarded the title Raden Mas
\end{abstract}


(RM), which later became his full name Raden Mas Soewardi Soeryaningrat. What does education mean? From the two thoughts of the educational figure above, it can be concluded that education is a conscious effort made by someone in printing knowledgeable, character, and religious people. Who are the real educators? According to Ki Hajar Dewantara educating in the real sense is the process of humanizing humanity, namely the appointment of humans to the human level. Educating more liberates people from aspects of inner life (autonomy of thinking and making decisions, dignity, democratic mentality). According to K.H.A. Wahid Hasyim, an educator is not only competent in the field of science, but must master the science of religion. He was guided by the words of the Prophet Muhammad "there is no religion, for people who are not intelligent". Why is education needed? Education takes place at any time, because remembering the human need for education itself is very high. To get an education there is no need for someone to wait for adulthood or the time they have the ability. But education continues as long as someone understands the benefits and functions of education. When does education take place? In understanding the reasons why education is needed, it will be more striking if understood from the aspect of the purpose of education itself. Humans are born with powerlessness, and have different advantages and disadvantages. Humans also have the potential that should be able to develop but humans have weaknesses. For this reason, the purpose of education is the process of human maturity which can bring up potentials in human beings. Where is the education conducted? Ki Hajar Dewantara, who mentioned that the learning environment contained three elements, namely what is known as the education center or tri education center consisting of the realm of the family, the nature of the paguron (school) and the realm of youth (the community). How is the 
process of implementing education? Based on the theory of learning levels proposed by Ki Hadjar Dewantara, there are four stages of learning. In the implementation of education K.H.A. Wahid Hasyim combines learning models in pesantren with modern learning.

Kata Kunci: Konsep 5W+1H, Pendidikan

\section{Pendahuluan}

Dewasa ini kata pendidikan sangat familiar di telingan masyarakat. Semua masyarakat merasakan akan hadirnya pendidikan di lingkungan sekitar. Pengertian pendidikan adalah pembelajaran pengetahuan, keterampilan, dan kebiasaan sekelompok orang yang diturunkan secara sadar dari satu generasi ke generasi dalam bentuk mengajaran, pelatihan atau pun penelitian. Dari pengertian pendidikan tersebut, dapat dipahami bersama bahwa pendidikan merupakan ilmu turunan yang akan diberikan dari seseorang atau kelompok guna memberikan pengetahuan dari generasi ke generasi. Dengan begitu hadirnya pendidikan sangat dibutuhkan oleh masyarakat dalam menghadapi perkembangan zaman.

Setiap manusia yang lahir ke dunia ini membawa berbagai aspek kehidupan baik yang menyangkut permasalahan jasmani maupun rohani, tetapi aspek tersebut masih berupa suatu potensi bukan sebuah barang jadi. Potensi-potensi pada manusia ini kemudian bisa ditumbuh kembangkan melalui sebuah proses yang disebut pendidikan. Pendidikan adalah pengaruh, bantuan atau tuntunan yang diberikan oleh orang yang bertanggung jawab kepada anak didik. ${ }^{1}$ Pengaruh dan tuntunan inilah yang membangun jati diri dalam diri manusia, sehingga memunculkan potensi untuk terus berkembang.

1 A. Soedomo Hadi, Pendidikan Suatu Pengantar. Surakarta: UNS Press, 2008, hlm. 18. 
Dengan begitu pendidikan sering dikatakan sebagai proses memanusiakan dan mutlak dibutuhkan bagi manusia.

Dalam Undang-Undang Sistem pendidikan Nasional No. 20 Tahun 2003 pasal 1 butir 1, pendididan adalah usaha sadar dan terencana untuk mewujudkan suasana belajar dan proses pembelajaran agar peserta didik secara aktif mengembangkan potensi dirinya untuk memiliki kekuatan spiritual keagamaan, pengendalian diri, kepribadian, kecerdasan, akhlak mulia, serta ketrampilan yang diperlukan dirinya, masyarakat, bangsa dan negara.

Dalam Undang-Undang Sistem Pendidikan Nasional Tahun 2003 pasal 1 dinyatakan bahwa tujuan pendidikan nasional adalah mengembangkan potensi 2 peserta didik untuk memiliki kecerdasan, kepribadian, dan akhlak mulia. Sebenarnya, amanat Undang-Undang Sistem pendidikan nasional bertujuan membentuk insan Indonesia yang cerdan dan berkepribadian atau berkarakter sehingga melahirkan generasi bangsa yang tumbuh dan berkembang dengan karakter yang bernapaskan nilai-nilai luhur bangsa dan agama.

Dengan demikian, pendidikan tidak hanya membentuk insan yang cerdas, tretapi juga berkepribadian atau berkarakter sehingga dapat melahirkan generasi bangsa yang tumbuh berkembang dengan karakter yang bernapas nilai-nilai luhur bangsa. $^{2}$

Tolak ukur kemajuan suatu Negara dapat dilihat salah satunya dengan keberhasilan pelaksanaan pendidikan. Pendidikan yang berhasil dapat dilihat dari kematangan pola pikir, kemajuan perekonimian dan dan menciptakan manusia yang berkarakter. Dengan begitu keberhasilan pendidikan menjadi tanggung jawab seluruh komponen masyarakat

${ }^{2}$ Anas Salahudin dan Irwanto Alkrienciehie. Pendidikan Karakter: Pendidikan Berbasis Agama dan Budaya Bangsa. (Bandung: CV. Pustaka Setia. 2013), h. 11 
terutama orang tua. Setiap pengalaman yang dilalui anak baik dari penglihatan, pendengaran, maupun perlakuan yang mereka terima merupakan suatu pendidikan. Dan hal tersebut akan menjadi tolak ukur mereka dalam berperilaku dan berpikir.

Dengan menilik penjelasan di atas, maka perlunya pemahaman dalam diri masyarakat mengenai pendidikan. Di dalam artikel ini akan membahas mengenai aspek-aspek pendidikan dalam $5 \mathrm{~W}+1 \mathrm{H}$. Yaitu What (Apa) makna pendidikan?, Who (Siapa) pendidik yang sebenarnya?, Why (Mengapa) pendidikan dibutuhkan?, When (Kapan) pendidikan berlangsung?, Where (Dimana) pendidkan dilaksanakan?, dan How (Bagaimana) proses pelaksanaan pendidikan?.

Dalam bahasa Indonesia, istilah pendidikan berasal dari kata "didik" dengan memberikan awalan "pe" dan akhiran "an", yang mengandung arti "perbuatan". Kata pendidkan berasal dari bahasa Yunani, yaitu paedagogos yang berarti pergaulan dengan anak-anak. Paedagogos (ahli didik atau pendidik) ialah seorang yang tugasnya membimbing anak, 2 sedangkan pekerjaan pembimbing di sebut paedagogis. Istilah ini kemudian di terjemahkan ke dalam bahasa Inggris dengan "education" yang berarti pengembangan atau bimbingan. ${ }^{3}$

Diketahui bersama ada banyak tokoh pendidikan yang muncul terutama di Indonesia dan untuk lebih memahami konsep $5 \mathrm{~W}+1 \mathrm{H}$ dalam artikel ini akan menelaah pemikiran $\mathrm{Ki}$ Hajar Dewantara dan K.H. A.Wahid HAsyim. Ki Hajar Dewantara merupakan tokoh pendidikan yang mempekrasai pendidikan di zaman penjajahan. Ki Hajar Dewantara sangat memperhatikan pendidikan bagi bangsa Indonesia, sehingga beliau dijuluki "Bapak Pendidikan". Dalam berbagai sumber tulisan tentang pendidikan Ki Hadar Dewantara, Pendidikan harus dimulai dari persamaan persepsi pemangku pendidikan

${ }^{3}$ Miftahul Ulum Dan Basuki, Pengantar Ilmu Pendidikan Islam : Konseptualisasi Pendidikan Dalam Islam (STAIN Ponorogo, 2006), h.3 
tentang mendidik itu sendiri. Menurut Ki Hajar Dewantara mendidik dalam arti yang sesungguhnya adalah proses memanusiakan manusia (humanisasi), yakni pengangkatan manusia ke taraf insani. Di dalam mendidik ada pembelajaran yang merupakan komunikasi eksistensi manusiawi yang otentik kepada manusia untuk dimiliki, dilanjutkan dan disempurnakan.

Sedangkan K.H. A. Wahid Hasyim merupakan tokoh pendidikan Islam. K.H. A. Wahid Hasyim berasal dari keluarga yang taat beragama, keluarga pesantren yang berpegang erat pada tradisi. K.H Abdul Wahid Hasyim adalah seorang tokoh yang dikenal sebagai seorang figur mata rantai yang menjembatani peradaban pesantren dengan peradaban Indonesia modern. Dia membawa pemikiran yang progresif dan sikap yang moderat dalam perdebatan tentang masalah keagamaan dan kebangsaan. Keberhasilan nya terbukti ketika dia dapat menjembatani perbedaan yang terjadi baik antara orang-orang tradisional dan orang-orang modernis di satu sisi, dan di sisi lain antara kaum beragama (Islam) dan kaum sekuler. Menurut K.H. A. Wahid Hasyim pendidikan harus memenuhi antara kebutuhan duniawi duniawi dan ukhrowi, moralitas dan akhlak, dengan titik tekan pada kemampuan kognisi (iman), afeksi (ilmu) dan psikomotor (amal, akhlak yang mulia). Tujuan pendidikan menurut K.H. A. Wahid Hasyim bersifat Teosentris (Ketuhanan) sekaligus Antroposentris (Kemanusiaan).

\section{Pembahasan}

\section{Biografi Ki Hajar Dewantara}

Ki Hadjar Dewantara dilahirkan di Yogyakarta pada tanggal 2 mei 1889. Beliau adalah putra kelima dari Soeryaningrat putra dari Paku Alam III. Pada waktu dilahirkan diberi nama Soewardi Soeryaningrat, karena beliau masih 
keturunan bangsawan maka mendapat gelar Raden Mas (RM) yang kemudian nama lengkapnya menjadi Raden Mas Soewardi Soeryaningrat. ${ }^{4}$

Ki Hadjar Dewantara mengganti nama itu ketika beliau berusia 39 tahun, alasan beliau mengganti nama menjadi $\mathrm{Ki}$ Hadjar Dewantara adalah karena keinginan beliau untuk lebih merakyat atau lebih dekat dengan rakyat. Dengan mengganti nama tersebut, akhirnya Ki Hadjar Dewantara dapat leluasa bergaul dengan rakyat kebanyakan. Sehingga dengan demikian perjuangannya menjadi lebih mudah diterima oleh rakyat pada masa itu. Menurut silsilah susunan Bambang Sokawati Dewantara, Ki Hadjar Dewantara masih mempunyai alur keturunan dengan Sunan Kalijaga. ${ }^{5}$

Dengan demikian selain berasal dari keturunan bangsawan Ki Hajar Dewantara juga memiliki garis keturunan ulama dari Sunan Kalijaga. Sebagai keturunan bangsawan dan ulama, Ki Hajar Dewantara dididik dan dibesarkan dalam lingkungan sosio cultural dan religious yang tinggi. Pendidikan yang di dapat Ki Hajar Dewantara dari lingkungan keluarga sudah mengarah pada nilai-nilai sosial dan keagamaan serta tersalurkan dengan sikap sopan santun, kesenian dan welas asih terhadap lingkungan sekitar. Dengan begitu jiwajiwa pendidik sudah tertanam dari dalam diri Ki Hajar Dewantara dari kecil.

Pada masa itu pendidikan sangatlah langka, hanya orang-orang dari kalangan Belanda, Tiong Hoa, dan para pembesar daerah saja yang dapat mengenyam jenjang pendidikan yang diberikan oleh pemerintah Belanda. Ki Hadjar Dewantara (Soewardi Soerjaningrat) kecil mendapat pendidikan formal pertama kali pada tahun 1896, akan tetapi ia

${ }^{4}$ Darsiti Soeratman, Ki Hadjar Dewantara, (Jakarta: Departemen Pendidikan dan Kebudayaan, 1983/1984), h. 8-9.

${ }^{5}$ Ibid, h. 171. 
kurang senang karena teman sepermainannya tidak dapat bersekolah bersama karena hanya seorang anak dari rakyat biasa. Hal ini yang kemudian mengilhami dan memberikan kesan yang sangat mendalam di dalam hati nuraninya, dalam melakukan perjuangannya baik dalam dunia politik sampai degan pendidikan. Ia juga menentang kolonialisme dan feodalisme yang menurutnya sangat bertentangan dengan rasa kemanusiaan, kemerdekaan dan tidak memajukan hidup dan penghidupan manusia secara adil dan merata. ${ }^{6}$

Sebagai tokoh nasional yang dihormati dan disegani baik oleh kawan maupun lawan, Ki Hadjar Dewantara sangat kreatif, dinamis, jujur, sederhana, konsisten, konsekuen dan berani. Wawasan beliau sangat luas dan tidak berhenti berjuang untuk bangsanya hingga akhir hayat. Perjuangan beliau dilandasi dengan rasa ikhlas yang mendalam, disertai rasa pengabdian dan pengorbanan yang tinggi dalam mengantarkan bangsanya ke alam merdeka. ${ }^{7}$ Karena pengabdiannya terhadap bangsa dan Negara, pada tanggal 28 November 1959, Ki Hadjar Dewantara ditetapkan sebagai "Pahlawan Nasional". Dan pada tanggal 16 Desember 1959, pemerintah menetapkan tanggal lahir Ki Hadjar Dewantara tanggal 2 Mei sebagai "Hari Pendidikan Nasional" berdasarkan keputusan Presiden RI Nomor: 316 tahun $1959 .{ }^{8}$

Ki Hadjar Dewantara meninggal dunia pada tanggal 26 Apri 1959, di rumahnya Mujamuju Yogyakarta. Dan pada tanggal 29 April, jenazah Ki Hadjar Dewantara dipindahkan ke

${ }^{6}$ Bambang S Dewantara, Mereka yang Selalu Hidup Ki Hadjar Dewantara dan Nyi Hadjar Dewantara, (Jakarta: Roda Pengetahuan, 1981), h. 15-16.

${ }^{7}$ Ki Hariyadi, Ki Hadjar Dewantara sebagai Pendidik, Budayawan, Pemimpin Rakyat, dalam Buku Ki Hadjar Dewantara dalam Pandangan Para Cantrik dan Mentriknya, (Yogyakarta: MLTS, 1989), H. 39.

${ }^{8}$ Ki Hadjar Dewantara, Karya Bagian I: Pendidikan, (Yogyakarta: MLPTS, cet II, 1962), h. XIII. 
pendopo Taman Siswa. Dari pendopo Taman Siswa, kemudian diserahkan kepada Majelis Luhur Taman Siswa. Dari pendopo Taman Siswa, jenazah diberangkatkan ke makan Wijaya Brata Yogyakarta. Dalam upacara pemakaman Ki Hadjar Dewantara dipimpin oleh Panglima Kodam Diponegoro Kolonel Soeharto. Dalam lingkungan budaya dan religius yang kondusif demikian Ki Hadjar Dewantara dibesarkan dan dididik menjadi seorang muslim khas jawa yang lebih menekankan aspek hakikat daripada syari'at. Dalam hal ini Pangeran Soeryaningrat pernah mendapat pesan dari ayahnya: "syari'at tanpa hakikat adalah kosong, hakikat tanpa syari' at batal". ${ }^{9}$

Selain mendapat pendidikan formal di lingkungan Istana Paku Alam tersebut. Ki Hadjar Dewantara juga mendapat pendidikan formal antara lain:

1. ELS (Europeesche Legere School). Sekolah Dasar Belanda III.

2. Kweek School (Sekolah Guru) di Yogyakarta.

3. STOVIA (School Tot Opvoeding Van Indische Artsen) yaitu sekolah kedokteran yang berada di Jakarta. Pendidikan di STOVIA ini tak dapat diselesaikannya, karena Ki Hadjar Dewantara sakit.

4. Europeesche Akte, Belanda 1914. ${ }^{10}$

\section{Biografi K.H.A. Wahid Hasyim}

Hari Jum'at Legi 5 Rabiul Awwal 1333 H bertepatan dengan 1 Juni 1914 di Jombang Jawa Timur,16 menjadi salah satu hari yang paling penting dalam perjalanan rumah tangga pasangan K.H. Hasyim Asy'ari dan Nyai Nafiqah17 binti Kyai Ilyas. Di hari itu lahir anak laki-laki pertama mereka yang diberi nama Abdul Wahid. Beliau merasa gembira dan

\section{${ }^{9}$ Ibid, h. 137}

${ }^{10}$ Gunawan, Berjuan Tanpa Henti dan Tak Kenal Lelah Dalam Buku Peringatan 70 Tahun Taman Siswa, (Yogyakarta:MLPTS, 1992, h. 302-303. 
bersyukur atas lahirnya bayi laki-laki yang melengkapi rumah tangga mereka. Namun mereka juga tidak memandang rendah anak perempuan yang telah lahir sebelumnya. Sebagai pendiri dan pengasuh pesantren besar dan terkemuka, beliau tentu sangat mendambakan munculnya orang yang dapat melanjutkan jejak langkah perjuangannya, yakni membesarkan dan mengembangkan pondoknya. ${ }^{11}$

Sebagaimana yang sudah diketahui bahwa Abdul Wahid yang di kemudian hari lebih dikenal dengan nama Wahid Hasyim berasal dari keluarga terpandang. Ayahnya, K.H. Hasyim Asy'ari adalah pendiri dan pengasuh Pesantren Tebuireng, Jombang. Di antara para ulama besar Indonesia kelahiran abad ke-19, tampak terlihat beliau lah yang paling terkemuka dan paling luas pengaruhnya bagi perkembangan dunia pendidikan. Beliau dikenal sangat ahli dalam bidang tafsir dan hadits, serta memiliki pengetahuan yang sangat mendalam tentang ilmu-ilmu keagamaan. Pesantren yang dipimpinnya juga melahirkan banyak ulama besar yang kemudian mendirikan pesantren.

Sejak kecil K.H. A.Wahid Hasyim sudah masuk Madrasah Tebuireng dan lulus pada usia 12 tahun. Selama mengenyam bangku sekolah, beliau giat mempelajari ilmu-ilmu kesusastraan dan budaya Arab secara outodidak. Beliau juga mempunyai hobi membaca yang sangat kuat dengan membaca selama lima jam dalam sehari. Beliau juga hafal banyak syair Arab yang kemudian disusun menjadi sebuah buku. Ketika berusia 13 tahun, K.H.A. Wahid Hasyim mulai melakukan pengembaraan mencari Ilmu. Awalnya beliau belajar di Pondok Siwalan, Panji, Sidoarjo. Di sana beliau mondok dari awal Ramadhan hingga tanggal 25 Ramadhan. Setelah itu pindah ke Pesantren Lirboyo, Kediri, sebuah pesantren yang didirikan

11 Ali Yahya, Sama Tapi Berbeda "Potret Keluarga Besar K.H.A Wahid Hasyim (Jombang: Yayasan K.H.A Wahid Hasyim, 2007), hal 3. 
oleh K.H. Abdul Karim, teman dan sekaligus murid ayahnya. Antara umur 13 dan 15 tahun, K.H.A. Wahid Hasyim menjadi Santri Kelana, pindah dari satu pesantren ke pesantren lainnya. Akhirnya pada tahun 1929 beliau kembali ke Pesantren Tebuireng. Ketika kembali ke Tebuireng, umurnya baru mencapai 15 tahun dan baru mengenal huruf latin. Dengan mengenal huruf latin, semangat belajarnya semakin bertambah. Beliau belajar ilmu bumi, bahasa asing, matematika, dll. Beliau juga berlangganan koran dan majalah, baik yang berbahasa Indonesia maupun bahasa Arab. Beliau mempelajari bahasa Asing berkat dorongan dari Ibunya yang ingin K.H.A. Wahid Hasyim tumbuh menjadi seorang yang pintar secara ilmu umum dan agama.

Wahid Hasyim mulai belajar Bahasa Belanda ketika berlangganan majalah tiga bahasa, "Sumber Pengetahuan" Bandung. Tetapi dia hanya mengambil dua bahasa saja, yaitu Bahasa Arab dan Belanda. Setelah itu dia mulai belajar Bahasa Inggris. ${ }^{12}$

\section{W+1H dalam Pendidikan menurut Ki Hajar Dewantara dan K.H.A. Wahid Hasyim What (Apa) makna pendidikan?}

Pendidikan dalam arti luas dapat diartikan sebagai usaha sadar dalam memberikan proses pembelajaran terhadap peserta didik dalam menuju proses pendewasaan dan kematangan peserta didik (manusia).

Menurut Ki Hajar Dewantara (Bapak Pendidikan Nasional Indonesia) menjelaskan bahwa "Pendidikan yaitu tuntutan di dalam hidup tumbuhnya anak-anak, adapun maksudnya, pendidikan yaitu menuntun segala kekuatan kodrat yang ada pada anak-anak itu, agar mereka sebagai manusia dan

12 A.Mubarok Yasin \& Fathurrahman Karyadi, Profil Pesantren Tebuireng (Jombang: Pustaka Tebuireng, 2011), hal 68-69. 
sebagai anggota masyarakat dapatlah mencapai keselamatan dan kebahagiaan setinggi-tingginya". Beliau juga membuat filosofi pendidikan yaitu ing ngarso sun tulodho, ing madya mangun karso, tut wuri handayani. Yang memiliki arti yaitu:

1. Ing Ngarso Sun Tulodho

Seorang pemimpin apabila di depan harus bisa memberi contoh atau memberi panutan bagi yang dipimpin atau warganya atau peserta didiknya. Disini dapat dipahami bersama bahwa bagi seorang pendidik harus selalu memperhatikan anak didiknya. Seorang pendidik harus bijaksana tidak dianjurkan bagi seorang pendidik untuk memaksakan kehendaknya agar senantiasa diikuti oleh anak didiknya. Teladan yang baik sangat diperhatikan dalam filosofi ini, maka dari itu seorang pendidik harus sadar bahwa setiap ucapan dan tingkah lakunya akan diikuti oleh anak didiknya.

2. Ing Madya Mangun Karso

Seorang pemimpin apabila berada di tengah-tengah masyarakat atau anak didik harus mampu membangkitkan semangat atau memberi motivasi supaya menjadi lebih baik atau lebih maju. Dalam hal dunia pendidikan filosofi ini dapat diartikan sebagai upaya yang diberikan seorang pendidik dalam menjadikan peserta didiknya menjadi lebih baik. Dalam artian ada perubahan dari segi tingkah laku ataupun pengetahuan. Seorang pendidik harus mampu menanamkan semangat belajar kepada anak didiknya dan tidak boleh membeda-bedakan anak didiknya.

3. Tut Wuri Handayani

Seorang pendidik apabila berada di belakang harus mendorong masyarakat atau anak didik yang dipimpin untuk menjadi lebih maju. Semboyan ini lebih cenderung kepada pemberian motivasi seorang pendidik kepada anak 
didiknya, tanpa memberadakan strata sosial, suku, ras dan budaya. Dengan begitu pendidik mampu mendorong kemajuan pendidikan dan mensukseskan visi misi Negara. ${ }^{13}$

Menurut KH. Abdul Wahid Hasyim bahwa untuk menjadikan orang beragama yang berpendidikan tidaklah perlu orang tersebut diharuskan mempunyai agama terlalu dalam dan luas. Sebalik nya, seseorang yang berpengetahuan agama tidak semua menjadi orang yang beragama dengan baik. Karena sering kali didapati seseorang yang tidak berpengetahuan agama dengan luas dan mendalam, kemudian beragama lebih sempurna dari orang yang berpengetahuan agama, dalam arti yang luas dan mendalam. Juga sebalik nya, sering di dapati orang yang sangat mengerti ilmu-ilmu agama yang mendalam, tetapi perbuatan nya tidak memberikan nama baik sebagaimana seharusnya seorang yang beragama. Oleh karena itu, pengetahuan tidak boleh di kungkung oleh perasaan keagamaan yang sempit.

KH.Wahid Hasyim menegaskan penting nya ilmu pengetahuan, atau dalam bahasa KH. Abdul Wahid Hasyim logika atau akal. Dia mengatakan bahwa Islam bukan saja menghargai akal dan otak yang sehat, tetapi menganjurkan orang supaya menyelidiki, memikirkan dan mengupas segala ajaran Islam. Dalam Islam logika adalah pokok yang penting bagi menentukan benar atau salah. Suatu hal atau suatu kejadian maupun suatu peristiwa yang menurut logika tidak dapat di terima, maka didalam anggapan Islam juga tidak dapat diterima. Islam tidak mengakui segala yang tidak tunduk pada logika. Namun, KH. Abdul Wahid Hasyim juga mengingatkan akan keterbatasan akal. Karena itu, meski tidak harus dikungkung agama, ilmu pengetahuan tetap harus dilengkapi

13

http://yakyono69.wordpress.com//2011/05/09/artikel.filsafatpendidikan-ki-hajar-dewantara 
dengan agama. Dengan agama itulah menurut KH. Abdul Wahid Hasyim, manusia bisa membedakan antara akal sehat dan hawa nafsu. ${ }^{14}$

Dari dua pemikiran tokoh pendidikan di atas dapat ditarik kesimpulan bahwa pendidikan adalah upaya sadar yang dilakukan seseorang dalam mencetak manusia-manusia yang berpengetahuan luas, berkarakter, dan beragama. Seseorang yang beragama tanpa didampingi dengan ilmu pengetahuan yang baik akan mempengaruhi proses pematangan diri. Begitupun sebaliknya apabila seseorang yang memiliki ilmu pengetahuan tanpa didasari agama yang kuat tidak dapat membedakan antara akal sehat dan hawa nafsu. Untuk itu antara agama dan ilmu pengetahuan harus berjalan dengan selaras dan seirama sehingga proses pendidikan yang didapat seseorang dapat berjalan dengan maksimal.

\section{Who (Siapa) pendidik yang sebenarnya?}

Menurut $\mathrm{Ki}$ Hajar Dewantara, pendidik adalah seseorang yang hendaknya menjadi pribadi yang bermutu dalam kepribadian dan kerohanian. Baru kemudian menyediakan diri untuk menjadi pahlawan dan juga menyiapkan peserta didik untuk membela nusa dan bangsa. Untuk itu seorang pendidik tidak hanya seorang guru yang ada di sekolah formal, tetapi seluruh komponen masyarakat yang ada di lingkungan pendidikan nonformal maupun informal. Dengan kata lain yang diutamakan menjadi seorang pendidik pertama-tama adalah fungsinya sebagai figure atau contoh, baru kemudian sebagai fasilitator atau pengajar. ${ }^{15}$

${ }^{14}$ Aboebakar Atjeh, Sejarah Hidup KH. A. Wahid Hasjim, (Jombang : Pustaka Tebuireng,2015), hal 687

15 http://www.teoripendidikan.com/2015/01/makalah-pendidikanmenurut-ki-hajar.html 
Menurut Ki Hajar Dewantara mendidik dalam arti yang sesungguhnya adalah proses memanusiakan manusia, yakni pengangkatan manusia ke taraf insani. Mendidik harus lebih memerdekakan manusia dari aspek hidup batin (otonomi berpikir dan mengambil keputusan, martabat, mentalitas demokratik). Ki Hajar Dewantara memberikan beberapa pedoman dalam menciptakan kultur positif seorang pendidik. Semboyan Trilogi pendidikan memiliki arti yang melibatkan seluruh pelaku pendidikan atau guru dan peserta didik adalah: Tut wuri handayani, dari belakang seorang guru harus bisa memberikan dorongan dan arahan. Ing madya mangun karsa pada saat di antara pesetra didik, guru harus menciptakan prakarsa dan ide. Ing ngarsa sung tulada, berarti ketika guru berada di depan, seorang guru harus memberi teladan atau contoh dengan tindakan yang baik. ${ }^{16}$

Menurut K.H.A. Wahid Hasyim, seorang pendidik tidak hanya cakap di bidang ilmu pengetahuan saja melainkan harus menguasai ilmu agama. Beliau berpedoman dari sabda Nabi Muhammad "tidak terdapat agama, bagi orang yang tidak berakal". Oleh karena itu seorang pendidik yang harus dikuasai adalah kematangan ilmu agamanya. Dengan kata lain, Wahid Hasyim mengatakan akal Manusia berkembang. Ilmu pengetahuan pun kian canggih. Agama, sementara itu, menyediakan sesuatu yang belum terpikirkan Manusia pada masanya. "Maka berpikir adalah perintah pertama dalam Islam," kata Wahid Hasyim saat berpidato mengumumkan agenda kerja Kementrian Agama 1951-1952. ${ }^{17}$

16 Wawan Eko Mujito., Pendidikan Agama Islam, Vol. XI, No. 1, Juni 2014

17 Tim Buku Tempo, Seri Tempo : Wahid Hasyim (Jakarta : Kepustakaan Populer Gramedia, 2016), hal 120 


\section{Why (Mengapa) pendidikan dibutuhkan?}

Dalam memahami alasan mengapa pendidikan dibutuhkan, maka akan lebih mengena jika dipahami dari aspek tujuan pendidikan itu sendiri. Manusia terlahir dengan ketidakberdayaan, dan memiliki kekurangan serta kelebihan yang berbeda-beda. Manusia juga memiliki potensi yang seharusnya dapat berkembang akan tetapi manusia memiliki kelemahan. Untuk itu tujuan pendidikan sebagai proses pendewasaan diri manusia yang mana dapat memunculkan potensi-potensi dalam diri manusia.

Menurut Ki Hajar Dewantara, tujuan pendidikan adalah penguasaan diri, sebab disinilah pendidikan memanusiakan manusia (humanisasi). Penguasaan diri merupakan langkah yang dituju untuk tercapainya pendidikan yang memanusiawikan manusia. Ketika peserta didik mampu menguasai dirinya, maka mereka akan mampu untuk menentukan sikapnya. Dengan demikian akan tumbuh sikap yang mandiri dan dewasa. Beliau juga menunjukkan bahwa tujuan diselenggarakannya pendidikan adalah membantu peserta didik menjadi manusia yang merdeka. Menjadi manusia yang merdeka berarti tidak hidup terperintah, berdiri tegak dengan kekuatan sendiri, dan cakap mengatur hidupnya dengan tertib. Dengan kata lain, pendidikan menjadikan seseorang mudah diatur, tetapi tidak dapat disetir. ${ }^{18}$

Pendidikan menurut Wahid Hasyim bertujuan untuk menggiatkan santri yang berakhlakul karimah, takwa kepada Allah serta memiliki keterampilan untuk hidup. Model lama tarbiyah Islam yang terjebak pada pendekatan teosentris juga beliau setting ulang dengan nuansa antroposentris sebagai upaya untuk membumikan ajaran Islam yang lebih realistis, faktual dan update. Dengan penekanan ini Kyai Wahid

18 http://tyanfedi.blogspot.com/2013/11/tujuan-pendidikan-menurutki-hajar.html. diakses hari Minggu, 5 Januari 2020 jam 12.54 WIB 
berharap agar nantinya para alumni mampu menjawab persoalan masyarakat. ${ }^{19}$

Menurut Wahid Hasyim tujuan pendidikan adalah untuk menggiatkan santri yang berakhlakul karimah, takwa kepada Allah dan memiliki ketrampilan untuk hidup. Artinya dengan ilmu yang di miliki ia mampu hidup layak di tengah masyarakat, mandiri dan tidak jadi beban bagi orang lain. Santri yang tidak mempunyai ketrampilan hidup ia akan menghadapi berbagai problematika yang akan mempersempit perjalanan hidup nya. Dengan demikian dapat di pahami bahwa tujuan pendidikan Wahid Hasyim bersifat Teosentris (ketuhanan) sekaligus Antroposentris (kemanusiaan). Artinya bahwa pendidikan harus memenuhi antara kebutuhan dunia dan ukhrowi. Serta moralitas dan akhlak. Titik tekan nya adalah pada kemampuan kognisi (iman), afeksi (ilmu), juga psikomotor (amal, akhlak yang mulia). ${ }^{20}$

\section{When (Kapan) pendidikan berlangsung?}

Pendidikan berlangsung kapanpun, karena mnengingat kebutuhan manusia terhadap pendidikan itu sendiri sangatlah tinggi. Untuk memperoleh pendidikan tidak ada keharusan bagi seseorang untuk menunggu masa dewasa atau masa mereka memiliki kemampuan. Akan tetapi pendidikan itu berlangsung selama seseorang mengerti tentang manfaat dan fungsi pendidikan itu.

K.H.A. Wahid Hasyim menjelaskan pelaksanaan pendidikan sesuai kaidah pendidikan Rasulullah SAW. yang paling simpel. Ia membolehkan semua golongan Manusia

19 LITERASI, Volume IX, No. 1 2018, (Nurhabibah, Pemikiran Wahid Hasyim tentang Pendidikan dan Relevansianya dengan Dunia Modern)

20 Shofiyullah, Revitalisasi Humanisme Religius dan Kebangsaan KH. Abdul Wahid Hasyim, (Jombang : Pesantren Tebuireng, 2011), h.74 
terlibat di dalam nya, walau dimanapun mereka berada dan pada waktu kapan saja. Artinya Rasulullah tidak membatasi pendidikan nya pada batas waktu atau batas umur atau tempat tertentu. Lihat sabda Baginda :

$$
\text { “، أُطلب العلم من المحد الى اللحد }
$$

Tuntutlah ilmu dari dalam buaian hingga ke liang lahat."

$$
\text { “ اطلب العلم ولو بالصين }
$$

Tuntutlah ilmu walau sampai ke Negeri Cina."

Kedua hadits tersebut merupakan kaidah tentang prinsip pendidikan sepanjang hayat dan prinsip pendidikan global dan terbuka. Prinsip pendidikan sepanjang hayat adalah prinsip yang menekankan agar setiap orang terus belajar dan meningkat kan dirinya sepanjang hayat. Hal tersebut di lakukan karena beberapa alasan. Pertama, setiap ilmu yang di pelajari suatu saat akan hilang atau lupa dari ingatan, karena tidak pernah di pelajari lagi. Dengan keadaan demikian, ia akan mengalami kesulitan ketika dalam pekerjaan yang akan di lakukan, ilmu tersebut sangat di butuhkan. Kedua, bahwa ilmu pengetahuan setiap saat mengalami perkembangan, pembaruan, bahkan pergantian, mengingat data yang di gunakan ilmu pengetahuan tersebut sudah berubah. Sehingga jika kita tidak terus menerus belajar, akan ketinggalan dari perkembangan, dan ilmu pengetahuan yang di miliki tidak ada gunanya di sebabkan sudah tidak relevan.

\section{Where (Dimana) pendidikan dilaksanakan?}

$\mathrm{Ki}$ Hajar Dewantara yang menyebutkan bahwa lingkungan belajar terdapat tiga unsur yaitu yang dikenal dengan istilah tripusat pendidikan atau tri sentra pendidikan yang terdiri dari alam keluarga, alam paguron (sekolah) dan alam pemuda (masyarakat). Menurut Ki Hajar Dewantara 
keluarga merupakan pusat belajar yang pertama dan utama, dikatakan demikian karena keluarga merupakan tempat belajar pertama kali yang dialami oleh anak. Keluarga memberikan dasar-dasar, sikap, dan keterampilan dasar seperti pengetahuan tentang agama. Kemudian sekolah merupakan penerus dari pendidikan keluarga. Pengetahuan yang tidak diberikan oleh keluarga diberikan di sekolah. Sememtara itu, didalam masyarakat mempunyai nilai-nlai sosial budaya dan peraturanperaturan yang dijunjung tinggi, dihayati, dan diamalkan. Nilainilai dan peraturan-peraturan tersebut selalu berubah dan berkembang sesuai dengan keadaan lingkungan pada waktu itu. Peserta didik dapat melaksanakan proses belajar dalam lingkungan masyarakat melalui interaksi dengan lingkungan sekitar. $^{21}$

\section{How (Bagaimana) proses pelaksanaan pendidikan?}

Menurut Ki Hajar Dewantara dalam pelaksanaan pendidikan seorang pendidik berkewajiban mengembangkan peserta didik sesuai dengan karakter peserta didik dan karakter lingkungan budaya setempat. Hal tersebuut bertujuan agar peserta didik dapat menguasai diri sendiri. Among metode merupakan pemeliharaan dan perhatian untuk mendapat pertumbuhan anak lahir dan batin sesuai dengan kodrat. Sistem among menurut Ki Hajar Dewantara berisi dua dasar, yaitu sebagai berikut:

a. Kemerdekaan sebagai syarat untuk menghidupkan dan menggerakkan kekuatan lahir dan batin, sehingga manusia dapat hidup merdeka (dapat berdiri sendiri).

b. Kodrat alam sebagai syarat untuk menghidupkan dan mencapai kemajuan dengan secepat-cepatnya dan sebaikbaiknya.

${ }^{21}$ Op.Cit. Wawan. Hal 69 
Berdasarkan teori tingkatan belajar yang dikemukakan oleh Ki Hadjar Dewantara, terdapat empat tahapan pembelajaran. Tahap perkembangan pertama peserta didik dibimbing untuk mengetahui pengertian mengenai kebaikan dan keburukan. Tahap kedua yaitu, setelah mengetahui pengertian mengenai kebaikan dan keburukan peserta didik diajarkan perilaku yang berkenaan dengan baik buruk menggunakan metode pembiasaan. Tahap ketiga, peserta didik dibimbing untuk mengetahui dan mengukur tindakan yang telah dilaksanakan. Tahap keempat, peserta didik dibimbing untuk memahami, menyadari, dan mempertanggung jawabkan perilaku yang telah dilaksanakan oleh peserta didik.

Dalam pelaksanaan pendidikan K.H.A. Wahid Hasyim memadukan antara model pembelajaran di pesantren dengan pembelajaran modern. Beliau menggunakan ruang kelas dengan kurikulum: $70 \%$ untuk pelajaran umum dan 30\% untuk pelajaran agama. Model kurikulum ini sampai saat ini masih di gunakan dalam pendidikan di Indonesia. Sedangkan dalam materi pelajarannya beliau menyeimbangkan antara materi umum, agama, dan keterampilan. Untuk metode sendiri, beliau mengadopsi metode tutorial sebagai ganti metode bondongan. Menurut beliau metode bondongan sudah tidak efektif dalam mengembangkan inisiatif santri.

\section{Kesimpulan}

Pendidikan merupakan usaha sadar yang diberikan seseorang melalui proses pembelajaran guna membentuk generasi yang berkarakter, berilmu dan beragama. Pendidikan sendiri diberikan oleh siapa saja yang mempunyai ilmu lebih kepada manusia yang belum berilmu. Dengan adanya pendidikan diharapkan mampu meningkatkan potensi yang ada dalam diri manusia. Berbicara mengenai pendidikan, ada 
beberapa tokoh yang berperan dalam membangun, mengoptimalkan, dan membentuk suatu pendidikan.

Dengan menilik penjelasan di atas, maka perlunya pemahaman dalam diri masyarakat mengenai pendidikan. Di dalam artikel ini akan membahas mengenai aspek-aspek pendidikan dalam $5 \mathrm{~W}+1 \mathrm{H}$. Yaitu What (Apa) makna pendidikan?, Who (Siapa) pendidik yang sebenarnya?, Why (Mengapa) pendidikan dibutuhkan?, When (Kapan) pendidikan berlangsung?, Where (Dimana) pendidkan dilaksanakan?, dan How (Bagaimana) proses pelaksanaan pendidikan?.

Berbicara mengenai pendidikan, ada beberapa tokoh yang berperan dalam membangun, mengoptimalkan, dan membentuk suatu pendidikan. Guna membatasi pemikiran para tokoh pendidikan, dalam artikel ini akan membahas konsep pendidikan dari Ki Hajar Dewantara dan K.H.A. Wahid Hasyim.

Abdul Wahid Hasyim lahir pada tanggal 1 juni 1914 M atau bertepatan dengan tanggal 5 Rab' al-awwal $1333 \mathrm{H}$ di Jombang, Jawa Timur. Dia adalah putra K.H Hasyim Asy'ari, pendiri Nahdlatul Ulama. Ki Hadjar Dewantara dilahirkan di Yogyakarta pada tanggal 2 mei 1889. Beliau adalah putra kelima dari Soeryaningrat putra dari Paku Alam III. Pada waktu dilahirkan diberi nama Soewardi Soeryaningrat, karena beliau masih keturunan bangsawan maka mendapat gelar Raden Mas (RM) yang kemudian nama lengkapnya menjadi Raden Mas Soewardi Soeryaningrat.

What (Apa) makna pendidikan?

Dari dua pemikiran tokoh pendidikan di atas dapat ditarik kesimpulan bahwa pendidikan adalah upaya sadar yang dilakukan seseorang dalam mencetak manusia-manusia yang berpengetahuan luas, berkarakter, dan beragama. Seseorang yang beragama tanpa didampingi dengan ilmu pengetahuan yang baik akan mempengaruhi proses pematangan diri. 
Begitupun sebaliknya apabila seseorang yang memiliki ilmu pengetahuan tanpa didasari agama yang kuat tidak dapat membedakan antara akal sehat dan hawa nafsu. Untuk itu antara agama dan ilmu pengetahuan harus berjalan dengan selaras dan seirama sehingga proses pendidikan yang didapat seseorang dapat berjalan dengan maksimal.

Who (Siapa) pendidik yang sebenarnya?

Menurut Ki Hajar Dewantara mendidik dalam arti yang sesungguhnya adalah proses memanusiakan manusia, yakni pengangkatan manusia ke taraf insani. Mendidik harus lebih memerdekakan manusia dari aspek hidup batin (otonomi berpikir dan mengambil keputusan, martabat, mentalitas demokratik). Ki Hajar Dewantara memberikan beberapa pedoman dalam menciptakan kultur positif seorang pendidik. Semboyan Trilogi pendidikan memiliki arti yang melibatkan seluruh pelaku pendidikan atau guru dan peserta didik adalah: Tut wuri handayani, dari belakang seorang guru harus bisa memberikan dorongan dan arahan. Ing madya mangun karsa pada saat di antara pesetra didik, guru harus menciptakan prakarsa dan ide. Ing ngarsa sung tulada, berarti ketika guru berada di depan, seorang guru harus memberi teladan atau contoh dengan tindakan yang baik.

Menurut K.H.A. Wahid Hasyim, seorang pendidik tidak hanya cakap di bidang ilmu pengetahuan saja melainkan harus menguasai ilmu agama. Beliau berpedoman dari sabda Nabi Muhammad "tidak terdapat agama, bagi orang yang tidak berakal". Oleh karena itu seorang pendidik yang harus dikuasai adalah kematangan ilmu agamanya. Dengan kata lain, Wahid Hasyim mengatakan akal Manusia berkembang. Ilmu pengetahuan pun kian canggih. Agama, sementara itu, menyediakan sesuatu yang belum terpikirkan Manusia pada masanya. "Maka berpikir adalah perintah pertama dalam 
Islam," kata Wahid Hasyim saat berpidato mengumumkan agenda kerja Kementrian Agama 1951-1952.

Why (Mengapa) pendidikan dibutuhkan?

Pendidikan berlangsung kapanpun, karena mnengingat kebutuhan manusia terhadap pendidikan itu sendiri sangatlah tinggi. Untuk memperoleh pendidikan tidak ada keharusan bagi seseorang untuk menunggu masa dewasa atau masa mereka memiliki kemampuan. Akan tetapi pendidikan itu berlangsung selama seseorang mengerti tentang manfaat dan fungsi pendidikan itu.

When (Kapan) pendidikan berlangsung?

Dalam memahami alasan mengapa pendidikan dibutuhkan, maka akan lebih mengena jika dipahami dari aspek tujuan pendidikan itu sendiri. Manusia terlahir dengan ketidakberdayaan, dan memiliki kekurangan serta kelebihan yang berbeda-beda. Manusia juga memiliki potensi yang seharusnya dapat berkembang akan tetapi manusia memiliki kelemahan. Untuk itu tujuan pendidikan sebagai proses pendewasaan diri manusia yang mana dapat memunculkan potensi-potensi dalam diri manusia.

Where (Dimana) pendidkan dilaksanakan?

$\mathrm{Ki}$ Hajar Dewantara yang menyebutkan bahwa lingkungan belajar terdapat tiga unsur yaitu yang dikenal dengan istilah tripusat pendidikan atau tri sentra pendidikan yang terdiri dari alam keluarga, alam paguron (sekolah) dan alam pemuda (masyarakat).

How (Bagaimana) proses pelaksanaan pendidikan?.

Berdasarkan teori tingkatan belajar yang dikemukakan oleh Ki Hadjar Dewantara, terdapat empat tahapan pembelajaran. Tahap perkembangan pertama peserta didik dibimbing untuk mengetahui pengertian mengenai kebaikan dan keburukan. Tahap kedua yaitu, setelah mengetahui pengertian mengenai kebaikan dan keburukan peserta didik 
diajarkan perilaku yang berkenaan dengan baik buruk menggunakan metode pembiasaan. Tahap ketiga, peserta didik dibimbing untuk mengetahui dan mengukur tindakan yang telah dilaksanakan. Tahap keempat, peserta didik dibimbing untuk memahami, menyadari, dan mempertanggung jawabkan perilaku yang telah dilaksanakan oleh peserta didik.

Dalam pelaksanaan pendidikan K.H.A. Wahid Hasyim memadukan antara model pembelajaran di pesantren dengan pembelajaran modern. Beliau menggunakan ruang kelas dengan kurikulum: $70 \%$ untuk pelajaran umum dan 30\% untuk pelajaran agama. Model kurikulum ini sampai saat ini masih di gunakan dalam pendidikan di Indonesia. Sedangkan dalam materi pelajarannya beliau menyeimbangkan antara materi umum, agama, dan keterampilan. Untuk metode sendiri, beliau mengadopsi metode tutorial sebagai ganti metode bondongan. Menurut beliau metode bondongan sudah tidak efektif dalam mengembangkan inisiatif santri.

\section{Referensi}

A. Soedomo Hadi, Pendidikan Suatu Pengantar. Surakarta: UNS Press, 2008, hlm. 18.

A. Mubarok Yasin \& Fathurrahman Karyadi, Profil Pesantren Tebuireng (Jombang: Pustaka Tebuireng, 2011), hal 6869.

Aboebakar Atjeh, Sejarah Hidup KH. A. Wahid Hasjim,

(Jombang : Pustaka Tebuireng, 2015), hal 687

Ali Yahya, Sama Tapi Berbeda "Potret Keluarga Besar K.H.A Wahid Hasyim (Jombang: Yayasan K.H.A Wahid Hasyim, 2007), hal 3.

Anas Salahudin dan Irwanto Alkrienciehie. Pendidikan Karakter: Pendidikan Berbasis Agama dan Budaya Bangsa. (Bandung: CV. Pustaka Setia. 2013), h. 11 
Bambang S Dewantara, Mereka yang Selalu Hidup Ki Hadjar Dewantara dan Nyi Hadjar Dewantara, (Jakarta: Roda Pengetahuan, 1981), h. 15-16.

Darsiti Soeratman, Ki Hadjar Dewantara, (Jakarta: Departemen Pendidikan dan Kebudayaan, 1983/1984), h. 8-9.

Gunawan, Berjuan Tanpa Henti dan Tak Kenal Lelah Dalam Buku Peringatan 70 Tahun Taman Siswa, (Yogyakarta:MLPTS, 1992, h. 302-303.

http://tyanfedi.blogspot.com/2013/11/tujuan-pendidikan-

menurut-ki-hajar.html. diakses hari Minggu, 5 Januari 2020 jam 12.54 WIB

http://www.teoripendidikan.com/2015/01/makalah-pendidikanmenurut-ki-hajar.html

http://yakyono69.wordpress.com//2011/05/09/artikel.filsafatpendidikan-ki-hajar-dewantara

Ki Hadjar Dewantara, Karya Bagian I: Pendidikan, (Yogyakarta: MLPTS, cet II, 1962), h. XIII.

Ki Hariyadi, Ki Hadjar Dewantara sebagai Pendidik, Budayawan, Pemimpin Rakyat, dalam Buku Ki Hadjar Dewantara dalam Pandangan Para Cantrik dan Mentriknya, (Yogyakarta: MLTS, 1989), H. 39.

LITERASI, Volume IX, No. 1 2018, (Nurhabibah, Pemikiran Wahid Hasyim tentang Pendidikan dan Relevansianya dengan Dunia Modern)

Miftahul Ulum Dan Basuki, Pengantar Ilmu Pendidikan Islam :

Konseptualisasi Pendidikan Dalam Islam (STAIN Ponorogo, 2006), h.3

Shofiyullah, Revitalisasi Humanisme Religius dan Kebangsaan KH. Abdul Wahid Hasyim, (Jombang : Pesantren Tebuireng, 2011), h.74

Tim Buku Tempo, Seri Tempo : Wahid Hasyim (Jakarta : Kepustakaan Populer Gramedia, 2016), hal 120 
Wawan Eko Mujito., Pendidikan Agama Islam, Vol. XI, No. 1, Juni 2014 